\title{
RESPONSABILIDADE CIVIL AMBIENTAL NO CONTEXTO DA SOCIEDADE DE RISCO
}

\author{
Celciane Malcher Pinto ${ }^{1}$
}

\section{RESUMO}

Este estudo visa tecer considerações sobre o dano ambiental e os novos paradigmas da responsabilidade civil ambiental em uma sociedade qualificada pelo risco. Neste sentido, são abordados alguns empecilhos para a concretização da responsabilidade objetiva diante das complexas situações envolvendo a lesão ao meio ambiente. Concluiu-se sobre a importância da incorporação de uma nova hermenêutica sobre a juridicidade do dano ambiental e das novas funções à responsabilidade civil através da observância de princípios estruturantes, como o Princípio da reparação integral. Quanto à metodologia utilizada trata-se de pesquisa bibliográfica e qualitativa.

Palavras Chave: Responsabilidade ambiental. Dano. Sociedade de risco. Teoria. Modernidade.

\section{ENVIRONMENTAL CIVIL RESPONSIBILITY IN THE RISK SOCIETY CONTEXT}

\begin{abstract}
This study aims to make considerations about environmental damage and the new paradigms of environmental liability in a society qualified by risk. In this sense, some obstacles are addressed for the realization of strict responsibility in the face of complex situations involving injury to the environment. It was concluded on the importance of incorporating a new hermeneutics on the legality of environmental damage and the new functions of civil liability through the observance of structuring principles, such as the Principle of integral reparation. As for the methodology used, it is a bibliographic and qualitative research.
\end{abstract}

Keywords: Environmental responsibility. Damage. Risk society. Theory. Modernity.

\section{Introdução}

O intenso processo produtivo, o consumo massificado e a desregrada utilização dos recursos ambientais advindos com o chamado avanço científico evidenciam uma nova configuração da modernidade: a sociedade de risco. Os riscos, antes considerados controláveis pelo homem europeu do século XIX, tornaram-se incalculáveis (mudança climática, crise financeira, desastres nucleares, terrorismo, etc.) e a categoria central para a

\footnotetext{
${ }^{1}$ Mestre em Direito Ambiental pelo Programa de Pós-Graduação em Direito Ambiental da UEA. Pós- graduada em Direito Penal e Processo Penal. Advogada. E-mail: celcymalcher@hotmail.com
} 
compreensão do contexto social atual e, especificamente, para o entendimento dos desastres naturais catastróficos.

Esta análise foi desenvolvida de forma particular através da teoria social elaborada pelo sociólogo alemão Ulrick Beck chamada de sociedade de risco, sendo este o aporte teórico adotado nesta pesquisa.

Sabe-se que foi adotada pelo ordenamento jurídico pátrio na seara ambiental, a teoria da responsabilidade objetiva fundada no risco apresentado pela atividade perigosa, sendo suprimida deste contexto a culpa, elemento fundamental da responsabilidade civil tradicional. Basta agora que sejam verificados o dano e o nexo causal. Mas tal tarefa nem sempre ocorre devido à complexidade que envolve os novos riscos ambientais.

Cabe destacar que os estudos sobre dano ambiental ganham grande importância na medida em que auxiliam a sociedade no processo de conscientização sobre a realidade ecológica do planeta e das consequências de suas degradações.

Pensar juridicamente sobre o dano ambiental e sua responsabilização requer inicialmente certos esclarecimentos referentes a tais institutos jurídicos bem como analisá-los considerando as interferências da nova qualidade dos riscos da atualidade, conforme propõe esta pesquisa. Assim, concentram-se as atenções sobre algumas considerações referentes à responsabilidade civil, ao estudo do dano ambiental e dos novos paradigmas da responsabilidade civil ambiental trazidos pela sociedade de risco.

\section{Noções gerais sobre Responsabilidade civil}

Diante do avanço tecnológico e da complexidade crescente envolvendo as relações sociais, a responsabilidade civil torna-se um assunto destacado no cotidiano cujo intuito principal volta-se para o ressarcimento daquele que sofreu o dano.

Para Paulo Antunes (2021, p. 234) dano seria a lesão causada a alguém por um terceiro que se vê obrigado ao seu ressarcimento. $O$ mesmo autor, considerando a complexidade relacionada ao conceito de dano enfatiza que sua origem tinha um conteúdo de cunho principalmente patrimonial não se considerando o dano de valor imaterial (íntimo) já que não possuía valor econômico.

No dizer de Helena Diniz (2021, p. 34) responsabilidade civil refere-se à aplicação de medidas que obriguem alguém a reparar o dano moral ou patrimonial causado a terceiros por ato próprio, por imposição legal ou de pessoa por quem este responda. A autora comenta a 
subdivisão embutida nesta definição acrescentando que em sua estrutura há a noção de culpa tratando-se de ato ilícito (responsabilidade subjetiva), e a do risco, ou seja, da responsabilidade sem culpa (responsabilidade objetiva).

O Código Civil brasileiro segue essencialmente a teoria subjetiva da responsabilidade que exige a verificação da culpa "latu sensu", ou seja, o agente causador do dano deverá ter sua culpa ou dolo comprovados. No entanto, a partir do Código de 2002, passam a conviver o sistema clássico de culpa (subjetiva) com a teoria do risco (objetiva) que ocorre quando prevista em lei ou quando a atividade que desempenha o causador do dano implica em riscos advindos de atividades perigosas.

Assim, a responsabilidade objetiva independe de culpa, o agente causador tem o dever de reparar o dano causado por seu empreendimento não importando se agiu com culpa ou não. Logo, para esta teoria o risco é um componente fundamental, havendo assim uma desconexão entre a reparação e o surgimento da culpa. A doutrina defensora desta teoria afirma que o que se busca é a socialização dos riscos levando em consideração a reparação mais abrangente dos danos causados aos entes da sociedade (público e privado).

Assim, verifica-se atualmente não se mostrar necessária ampla discussão sobre a culpa, conforme afirma Antunes (2021, p. 152-153).

\begin{abstract}
(...) a culpa, de grande estrela dos códigos civis modernos, está, a cada dia que passa, constituindo-se em uma categoria jurídica que não mais impressiona. A diminuição da importância da culpa é um fenômeno que se verifica em todo o mundo industrializado, como consequência da própria industrialização. O estado moderno, diante das repercussões da industrialização, fez algumas opções políticas visando mitigar-lhe os efeitos sociais.
\end{abstract}

Ao comentar a responsabilidade objetiva tendo por base a teoria do risco, ensina Gonçalves (2019, p.95) “[...] uma atividade que possa oferecer algum perigo representa, sem dúvida, um risco que agente assume de ser obrigado a ressarcir os danos que venham resultar a terceiros".

Os fins da responsabilidade sem culpa buscam propiciar a pacificação social com a reparação dos danos causados, fato que gradualmente afasta o modelo clássico de responsabilidade conforme pontua Feitoza (2012, p.132):

A partir do momento em que o dano se tornou anônimo, ou seja, sem a identificação efetiva de quem produziu, haverá o direito, por sua vez, de responder aos anseios de justiça, paz social e equidade, produzindo a responsabilidade sem formular questões 
subjetivas como usualmente se indagava a respeito da presença ou da ausência de culpa, para dotar a vítima da almejada indenização.

A seguir, será abordada a responsabilidade ambiental onde é possível notar-se a necessidade de uma adequação dos mecanismos de proteção do meio ambiente à complexidade das lesões ambientais no contexto da sociedade de risco.

\section{Fundamentos da Responsabilidade civil por dano ambiental no ordenamento jurídico pátrio}

Conforme o disposto no art. 225, $\S 3^{\circ}$ da Constituição Federal de 1988 existe a chamada responsabilidade tridimensional: a administrativa, a criminal e a civil. Será tratada neste tópico a responsabilidade civil imposta ao agente causador do dano ambiental.

Com o intuito de se elaborar mecanismos jurídicos para prevenção dos danos ambientais houve um movimento até início da década de 70, pelos seguintes motivos elencados por Benjamin (1998, p. 7):

1) funcionais (a tradicional visão da responsabilidade civil como instrumento post factum, destinado à reparação e não à prevenção de danos; 2) técnicas (inadaptabilidade do instituto à complexidade do dano ambiental, exigindo, por exemplo, um dano atual, autor e vítima claramente identificados, comportamento culposo e nexo causal estritamente determinado); 3) éticas (na hipótese de terminar em indenização, sendo impossível a reconstituição do bem lesado - a responsabilidade civil obriga, em última análise, a agregar-se um frio valor monetário à natureza, comercializando-a como tal).

Na década de 80, tendo em vista a demora do direito público em castigar os agentes degradadores do meio ambiente, tal situação excitou uma nova reflexão sobre a necessidade de se repensar a responsabilização, como é verificada tanto na Lei 6389/81quanto na Constituição Federal de 1988.

Tratando sobre os problemas relacionados à insuficiência do sistema clássico de responsabilidade na seara ambiental leciona Milaré (2020, p. 1.248):

Primeiro, pela natureza difusa deste, atingindo, via de regra, uma pluralidade de vítimas, totalmente desamparadas pelos institutos ortodoxos do Direito Processual clássico, que só ensejavam a composição do dano individualmente sofrido. Segundo pela dificuldade de prova da culpa do agente poluidor, quase sempre coberto por aparente legalidade materializada em atos do Poder Público, como licenças e autorizações. Terceiro, porque no regime jurídico do Código Civil, então, aplicável, admitiam-se as clássicas excludentes de responsabilização, como, por exemplo, caso fortuito e força maior. 
Inicialmente, tratando-se da conceituação do dano ambiental, Silva (2021, p. 302) define dano ecológico como "qualquer lesão ao meio ambiente causada por condutas ou atividades de pessoa física ou jurídica de Direito Público ou de Direito Privado”.

A Lei $n^{\circ}$ 6.938/81 não definindo expressamente dano ambiental acabou interligando este ao conceito de poluição. Assim dispõe no artigo $3^{\circ}$, III, da referida Lei de Política Nacional do Meio Ambiente, in verbis:

Art $3^{\circ}$ - Para os fins previstos nesta Lei, entende-se por:

$[\ldots]$

III - poluição, a degradação da qualidade ambiental resultante de atividades que direta ou indiretamente:

a) prejudiquem a saúde, a segurança e o bem-estar da população;

b) criem condições adversas às atividades sociais e econômicas;

c) afetem desfavoravelmente a biota;

d) afetem as condições estéticas ou sanitárias do meio ambiente;

e) lancem matérias ou energia em desacordo com os padrões ambientais estabelecidos;

Apresentando uma conceituação ambivalente de dano ambiental que leva em consideração os efeitos deste dano na vida das pessoas leciona Leite e Ayala (2015, p.104):

[...] constitui uma expressão ambivalente, que designa, certas vezes, alterações nocivas ao meio ambiente e outras, ainda, os efeitos que tal alteração provoca na saúde das pessoas e em seus interesses. Dano ambiental significa, em uma primeira acepção, uma alteração indesejável ao conjunto de elementos chamados meio ambiente, como, por exemplo, a poluição atmosférica; seria, assim, a lesão ao direito fundamental que todos têm de gozar e aproveitar do meio ambiente apropriado. Contudo, em sua segunda conceituação, dano ambiental engloba os efeitos que esta modificação gera na saúde das pessoas e em seus interesses.

No mesmo sentido, Rodrigueiro (2004, p.168) ao tratar sobre dano ambiental o define como qualquer agressão aos componentes ambientais que poderá repercutir indiretamente sobre a vida das pessoas de forma indivisível. Comenta ainda que a natureza difusa desta agressão poderá ter reflexos patrimoniais e extrapatrimoniais.

Assim, verifica-se no dizer dos referidos autores uma visão mais aprofundada de dano ambiental que faz referência não apenas as lesões aos recursos ambientais em si, que são comuns à coletividade, mas também apontam que os efeitos destes danos poderão provocar outra espécie de dano ambiental ligado ao prejuízo social subjetivo causado aos titulares de direitos difusos. 
No ordenamento jurídico-ambiental brasileiro o surgimento da responsabilidade objetiva ocorreu pela primeira vez no Decreto n. 79.347 de 28.3.77 que promulgou a Convenção Internacional sobre Responsabilidade em Danos causados em fase de poluição por óleo (1969). Em seguida, também a Lei n. 6.453, de 17.10.77, no seu art. 4º caput, recepcionou a responsabilidade objetiva com relação aos danos advindos de atividade nuclear.

A responsabilidade objetiva por danos ambientais foi consagrada pela Lei 6.938/81, que dispõe sobre a Política Nacional do Meio Ambiente. Assim aponta o art. 14, $\S 1^{\circ}$, in verbis:

Art. 14 - Sem prejuízo das penalidades definidas pela legislação federal, estadual e municipal, o não cumprimento das medidas necessárias à preservação ou correção dos inconvenientes e danos causados pela degradação da qualidade ambiental sujeitará os transgressores:

[...].

$\S 1^{\circ}$ - Sem obstar a aplicação das penalidades previstas neste artigo, é o poluidor obrigado, independentemente da existência de culpa, a indenizar ou reparar os danos causados ao meio ambiente e a terceiros, afetados por sua atividade. $\mathrm{O}$ Ministério Público da União e dos Estados terá legitimidade para propor ação de responsabilidade civil e criminal, por danos causados ao meio ambiente [...]. (grifo nosso).

Tal previsão legal foi recepcionada pela Constituição de 1988 em seu art. 225 , § $3^{\circ}$, não podendo, portanto, ser alterado por lei ordinária. Levando-se em consideração suas consequências importantes, Destefenni (2005, pp. 147-148) lembra que a adoção da teoria do risco integral deve:

a) afastar das demandas ambientais qualquer discussão acerca da culpa;

b) limitar a incidência de causas excludentes da responsabilidade;

c) tornar irrelevante a alegação de licitude da atividade desenvolvida pelo causados do dano;

d) minimizar a carga probatória do demandante, no que diz respeito ao nexo causal;

e) determinar uma responsabilidade objetiva no caso de ação e omissão;

f) determinar a aplicação do regime da responsabilidade objetiva mesmo na reparação dos danos sofridos por particulares.

Comenta Milaré (2020, pp. 1.246-1.250) que a teoria da responsabilidade objetiva ou teoria do Risco possui várias modalidades, das quais se destaca o risco proveito, o risco profissional, o risco excepcional, o risco administrativo ou risco criado, e o risco integral. Considerável parte da doutrina afirma que a responsabilidade civil ambiental é baseada na teoria do risco integral visto que não restam dúvidas quanto à sua vinculação a 
responsabilidade objetiva uma vez que esta atende à preocupação de se estabelecer um modelo o mais rígido possível, ante o quadro de degradação mundial. Com relação aos pressupostos da responsabilidade objetiva ambiental, diante da teoria do risco, basta a presença do evento danoso e o nexo causalidade.

No mesmo sentido defende Venosa (2016, p. 219-220):

Basta, portanto, que o autor demonstre o dano e o nexo causal descrito pela conduta e atividade do agente. Desse modo, não se discute se a atividade do poluidor é lícita ou não, se o ato é legal ou ilegal: no campo ambiental o que importa é reparar o dano. A noção de ato ilícito passa, então, [...]. Verifica-se, portanto, que em matéria de dano ambiental, foi adotada a teoria da responsabilidade objetiva na modalidade do risco integral.

Embora haja posicionamentos contrários, a doutrina majoritária defende que se torna irrelevante para a reparação do dano a ocorrência de caso fortuito e força maior. Esta é a interpretação dada pelos doutrinadores a Lei de Política Nacional do Meio ambiente, devendo o poluidor assumir integralmente pelo ambiental proveniente de sua atividade.

Sendo assim, a busca pelo status quo anterior ao dano ambiental é uma das principais funções da responsabilidade civil em matéria ambiental, verificando sua importância na medida em que funciona como mecanismo que evita os danos ambientais e promove a sua reparação.

Com o advento da sociedade industrial e sua atuação predatória ao meio ambiente, a doutrina aponta como características peculiares: A ampla dispersão das vítimas, a dificuldade inerente à ação reparatória e a dificuldade de sua valoração. Quanto às formas de reparação há duas formas principais conforme aponta Milaré (2020, p.1.125) “[...] (i) a restauração natural ou in specie; e (ii) a pecuniária. Não estão elas hierarquicamente em pé de igualdade”. Sobre como deve ser feito o ressarcimento do dano ambiental leciona Fiorillo (2020, p. 39).

[...] primeiramente, deve-se verificar se é possível o retorno ao status quo ante por via da específica reparação, e só depois de infrutífera tal possibilidade é que deve recair a condenação sobre um quantum pecuniário, até mesmo porque, por vezes, é difícil a determinação do quantum a ser ressarcido pelo causador do ato feito, sendo sempre preferível a reparação natural, pela recomposição efetiva e direta do ambiente prejudicado'. (grifo do autor). 
Para Leite e Ayala (2015, p. 221) estas duas formas de reparação do dano ambiental são patrimoniais sendo que a indenização pecuniária independe da reparação do dano extrapatrimonial ambiental.

Importante observar que a composição do dano através da restauração natural pode acontecer de dois modos: a restauração ecológica e a compensação ecológica. Na primeira hipótese, busca-se a recuperação do local da área degradada. Na segunda, a intenção é substituir os bens prejudicados por outros análogos, ou seja, busca-se uma equivalência ecológica do ambiente (MILARÉ, 2020, pp. 1.126 - 1.127).

A reparação natural, que embora na maioria dos casos seja mais onerosa, mostra-se a forma ideal de restauração com a busca pelo status quo anterior à lesão ou adotando-se as medidas de compensação, por esse motivo, somente quando não for possível a restauração in natura é que se permite a composição monetária (dano patrimonial).

No tocante há pluralidade de responsáveis pelo dano ambiental, todos devem responder solidariamente, uma vez que o que se busca é a total reparação do prejuízo causado, conforme de depreende do art. 942, caput, do Código Civil.

Assim, levando-se em consideração a imprecisão no caso de não se poder identificar entre vários degradadores ambientais, não seria justo que a reparação não ocorresse. Sendo assim, o poluidor que pagar integralmente pelo dano causado poderá intentar ação de regresso contra os outros co-responsáveis, pela via da responsabilidade subjetiva, a fim de discutir a parcela de responsabilidade de cada um. (MILARÉ, 2020, p.1.261)

Em relação à responsabilização do Estado, a Lei no 6.938/81 em seu artigo $3^{\circ}$, inciso IV, conceitua como poluidor a pessoa física ou jurídica, de direito público ou privado, responsável, direta e indiretamente, por atividade causadora de degradação ambiental. Sobre o assunto comenta Milaré (2020, p. 1.262):

\footnotetext{
Assim, afastando-se da imposição legal de agir, ou agindo deficientemente, deve o Estado responder por incúria, negligência ou deficiência, que traduzem um ilícito ensejador do dano não evitado que, por direito, deveria sê-lo. Neste caso, reparada a lesão, a pessoa jurídica de direito público em questão poderá demandar regressivamente o direito causador do dano.
}

Dessa forma, também o Estado poderá responder tanto como agente poluidor como também quando se omite do dever de fiscalizar e proteger o meio ambiente. 


\section{Classificação do dano ambiental}

A doutrina de Leite e Ayala (2015, p.108) aborda a classificação do dano ambiental da seguinte forma: quanto à amplitude do bem protegido, em: dano ecológico puro, dano ambiental amplo e dano ambiental individual ou reflexo; quanto à reparabilidade e ao interesse envolvido, em: dano de reparabilidade direta e de reparabilidade indireta; quanto aos interesses objetivados na tutela jurisdicional pretendida, em: dano ambiental de interesse da coletividade e dano ambiental de interesse individual; e quanto a extensão em: danos patrimoniais e extrapatrimoniais.

\subsection{Dano Ambiental Puro, Amplo e Individual (ou Reflexo)}

Considerando a classificação do dano ambiental no que diz respeito à amplitude do bem protegido, para que se compreenda o dano ecológico puro necessário atentar para o que leciona Leite e Ayala (2015, p.105) “[...] o meio ambiente pode ter uma conceituação restrita, ou seja, relacionada aos componentes naturais do ecossistema e não ao patrimônio cultural ou artificial".

Sendo assim, a fauna, a flora, e todos os demais elementos puramente naturais (específicos do ecossistema) comporiam essa espécie de dano.

Por outro lado, o dano ambiental amplo refere-se a um dano ambiental visto em sua totalidade (natural, artificial, cultural e do trabalho), ou seja, aquele provocado ao sistema ecológico como um todo.

As palavras de Leite e Ayala (2015, p.105) resumem bem este dano ambiental como sendo "[...] latu sensu, ou seja, concernente aos interesses difusos da coletividade, abrangeria todos os componentes do meio ambiente, inclusive o patrimônio cultural. Assim, estariam sendo protegidos o meio ambiente e todos os seus componentes, em uma concepção unitária”.

Já quanto ao dano ambiental individual ou reflexo embora o que imediatamente se pretenda proteger seja o patrimônio e os interesses particulares dos indivíduos, de forma indireta busca-se a proteção do meio ambiente coletivo, sendo assim uma ação reflexa, de forma parcial e limitada.

Sobre este gênero ambiental individual comenta Leite e Ayala (2015, p.162) “[...] levando em consideração que a lesão patrimonial ou extrapatrimonial que sofre o proprietário, em seu bem, ou a doença que contrai uma pessoa, inclusive a morte, podem ser oriundas da lesão ambiental". 
Sendo assim, quando este dano que afetou negativamente a qualidade do meio ambiente repercute além da coletividade para causar danos aos bens particulares pode ser chamado de dano ricochete ou reflexo, visto que de forma reflexa atingiu bens patrimoniais e extrapatrimoniais individuais. (MILARÉ, 2020, p. 1.122)

A reparação deste dano que atinge o particular pode ser buscada através de ação indenizatória, sendo a responsabilidade do infrator objetiva.

4.2 Dano Ambiental de interesse da coletividade e de interesse individual

Quanto aos interesses objetivados, o dano de interesse da coletividade e o de interesse individual são definidos da seguinte forma por Leite e Ayala (2015, p.107):

1. De um lado, o interesse da coletividade em preservar o macrobem ambiental sendo, então, chamado dano ambiental de interesse da coletividade ou de interesse público; 2. De outro lado, o interesse particular individual próprio, ambos relativos às propriedades das pessoas e a seus interesses (microbem), concernente a uma lesão ao meio ambiente que se reflete no interesse particular da pessoa, e no caso, sendo chamado dano ambiental de interesse individual.

Em se tratando de dano ambiental de interesse da coletividade ocorre uma lesão ao macrobem cuja reparação é de interesse coletivo stritu sensu ou difuso conforme menciona a doutrina de Carvalho (2001, p. 197) “dizem respeito aos sinistros causados ao meio ambiente lato sensu, repercutindo em interesses difusos, pois lesam diretamente uma coletividade indeterminada ou indeterminável de titulares”.

Entre os instrumentos de tutelas dos interesses da coletividade está a ação civil pública e o mandado de segurança coletivo e que devido a importância desses interesses e da difusão das vítimas, o Ministério Público tem a obrigação de promover as medidas processuais de reparação e prevenção do dano ambiental coletivo. (MILARÉ, 2020, p. 1.121).

\subsection{Dano Patrimonial e Extrapatrimonial}

Segundo Fiorillo (2020, p. 51) o dano patrimonial é uma lesão (prejuízo) ligada a interesses materiais de forma individual ou coletiva (com reflexos no campo individual ou metaindividual), representada pela lesão ou mesmo pela perda (parcial e integral) de referidos bens materiais (corpóreos). 
Os resultados advindos de contaminações do meio ambiente, bem como os fatos naturais que acarretam degradação que possam causar prejuízos reflexos aos bens individuais ou coletivos são chamados de danos ambientais patrimoniais.

Este dano ambiental pode ser reconhecido por suas consequências patrimoniais conforme menciona Leite e Ayala (2015, p.106):

Dano patrimonial ambiental, relativamente à restituição, recuperação, ou indenização do bem ambiental lesado. Saliente-se que esta concepção de patrimônio difere da versão clássica de propriedade, pois o bem ambiental, em sua versão de macrobem, é de interesse de toda coletividade. Entretanto, aplica-se a versão clássica de propriedade quando se tratar de microbem ambiental, pois diz respeito a um interesse individual e a um bem pertencente a este.

Já quanto ao dano extrapatrimonial diz respeito à lesão ao meio ambiente ecologicamente equilibrado causado à coletividade de cunho imaterial e ligado a valores como a saúde e a qualidade de vida das pessoas, ou seja, gera impactos nos sentimentos de uma comunidade atingida (LEITE; AYALA, 2015, p.299).

No dizer de Fiorillo (2020, p. 51) dano moral refere-se a uma lesão que venha ofender interesse que não seja corpóreo de forma individual e coletiva (com reflexos no campo individual ou metaindividual), constituída pela ofensa de valores imateriais como a "paz interior" da pessoa humana tutelados pela Constituição Federal.

A respeito da busca pela afirmação do aclamado dano moral ambiental e o silêncio da maioria dos doutrinadores ambientais sobre o tema assim comenta Rodrigueiro (2004, p.177):

O que pretendemos, pois, provar, é a existência de um dano superior, um dano maior, alheio à questão da pura devastação de uma mata, da destruição de espécies da fauna ou da flora, da camada de ozônio etc., buscamos concretizar a existência de um dano que atinge exclusivamente os titulares dos direitos difusos por excelência, quais sejam, todos nós.

Afirmar este dano que denominamos "Dano Moral Ambiental" a princípio nos pareceu tarefa complexa porque muitos estudiosos e notadamente aqueles que lidam com o direito ambiental, na maioria das vezes, calam-se diante da existência do dano moral ambiental.

Se estiver configurada a diminuição da qualidade de vida da população em relação ao patrimônio ambiental lesado é o que basta, conforme leciona Rodrigueiro (2004, p.182):

Do mesmo modo, o dano moral coletivo é evidente que para o mesmo existir um desastre ou um mero acidente ecológico há que haver e, com isto, espécies, água, ar, foram afetados, devem ser recompostos, mas o dano moral permanece, ainda que o 
próprio meio ambiente tenha, por si só, retomado as coisas a seu estado anterior, mesmo assim prevalece a existência do dano moral, é o que se tem entendido, pela letra de alguns doutrinadores afirmando a existência do dano moral coletivo e em consequência, aceitando o dano moral ambiental, de expressa previsão legal.

\title{
5. Responsabilidade civil, dano ambiental na sociedade de risco e novos paradigmas
}

Como visto, embora a responsabilidade objetiva ambiental seja reconhecidamente avançada em relação ao sistema civil tradicional ainda persistem certos entraves para sua efetivação muito relacionados com a globalidade das novas ameaças que fogem ao controle científico.

Considerando que as normas ambientais vigentes não são capazes de controlar os riscos da sociedade atual, se faz necessário que a responsabilidade civil ambiental no contexto da sociedade de risco paute-se em instrumentos de precaução e prevenção lançando novos olhares sobre questões como nexo de causalidade e tolerabilidade dentre outros (LEITE; AYALA, 2015, p.130).

Conforme tratado anteriormente, a responsabilidade civil objetiva por dano ambiental foi consagrada no parágrafo $1^{\circ}$ do art. 14 da Lei 6.938 de 1981 e posteriormente reafirmada pela Constituição Federal de 1988 em seu art. 225, uma vez que tais dispositivos preveem a obrigação de reparar o dano independente da ocorrência de culpa. Diante disso, importante destacar algumas diferenças entre o dano tradicional e o dano ambiental, conforme resume Leite e Belchior (2012, p. 28):

\begin{abstract}
Enquanto o dano tradicional esta vinculado à pessoa e aos seus bens considerados de forma individual, o ambiental é difuso, de titularidade indefinida ou indeterminável, haja vista que protege um bem de interesse difuso de uso comum do povo. Pode, ainda, gerar um dano ambiental reflexo quando a lesão também atinge indivíduos. [...] A lesão tradicional está amparada na certeza, na segurança, uma vez que não há dúvida do dano ocorrido, sendo o mesmo definido, além de possuir quase sempre certa visibilidade. O dano ambiental, ao revés, em virtude da teoria do risco, pode ser incerto, o que é de difícil constatação. Ainda nessa linha, constata-se que a lesão individual é sempre atual, permanente e clara. Possui, ainda a característica de anormalidade. $\mathrm{O}$ dano ambiental, por outro lado, pode ser transtemporal, além de ser cumulativo de geração em geração. Diferentemente da tradicional, a lesão ambiental pode ser oriunda de uma anormalidade, mas há possibilidade de existir uma tolerância social do dano.
\end{abstract}

Neste sentido, vale tecer algumas considerações sobre os princípios ambientais da prevenção e da precaução. Importante observar que existem divergências doutrinárias sobre se tais princípios são distintos ou não, embora nesta pesquisa sejam considerados como 
diferentes visto que a precaução contempla maior proteção do que a prevenção, embora ambos tenham função inibitória. Para Milaré (2020, p. 1.069) o princípio da prevenção se aplica quando se sabe antecipadamente (convicção científica) que determinada atividade causará degradação ao meio ambiente a fim de evitá-la. Já quando há incerteza científica sobre se determinada prática causará ou não degradação ambiental, tratar-se-á do princípio da precaução.

Fazendo referência a Teoria da Sociedade de risco, tais princípios estabelecem interessante relação com as duas formas de riscos ecológicos apontados por Beck. Estas formas segundo o autor seriam: (I) o risco concreto ou potencial (visível) que seria previsível pelo conhecimento humano; (II) e o risco abstrato (invisível) baseado na probabilidade de sua ocorrência (LEITE; AYALA, 2015, p.126). Sendo assim, o princípio da prevenção trataria dos riscos ambientais concretos ou potenciais enquanto que o princípio da precaução estaria ligado aos danos ambientais abstratos. Este último tipo de risco tem atormentado o homem pós-moderno frente a seu alto grau de imprevisibilidade e periculosidade, motivo pelo qual ganha cada vez mais importância o princípio da precaução.

Sobre as novas funções da responsabilidade civil ambiental aponta sinteticamente Leite e Belchior (2012, p. 33):

[...] englobam a prevenção e precaução do dano, que inibem a ação agressiva sobre o
meio; a internalização dos custos ambientais; a pedagógica; o encorajamento dos
investimentos da empresa e desenvolvimento para aumentar o conhecimento e
melhorar a tecnologia; o fomento de atitudes mais responsáveis por parte dos
poluidores; e, ainda, a restrição da instalação de empresas irresponsáveis instaladas
no país.

Outro ponto questionado refere-se ao fato de que para haver a responsabilidade civil por dano ambiental é necessário haver uma relação de causa e efeito que ligue um dano e uma conduta, chamado de nexo de causalidade que segundo Bahia $(2012$, p. 78) "[...] apresenta como funções primordiais identificar o agente responsável pela produção do resultado lesivo e apresentar parâmetros objetivos para a aferição da extensão do ressarcimento".

Quando se compara a comprovação do liame causal no dano tradicional e no dano ambiental verifica-se que é mais fácil de ocorrer no primeiro caso, uma vez que, para a lesão ambiental adotou-se a responsabilidade objetiva que dispensa a culpa do agente sendo necessário provar um possível nexo entre o dano e o responsável poluidor que deve suportar 
todos os riscos relativos à sua atividade potencialmente poluidora, onde segundo Milaré (2020, p.1.254) “[...] Analisa-se a atividade, indagando-se se o dano foi causado em razão dela, para se concluir que o risco que lhe é inerente é suficiente para estabelecer o dever de reparar o prejuízo".

O liame de causalidade representa uma das maiores dificuldades quando se discute a responsabilidade em questão, visto que, segundo Steigleder (2004, p. 196) “o dano pode ser resultado de várias causas concorrentes, simultâneas e sucessivas, dificilmente tendo uma única e linear fonte". Um exemplo, neste sentido é a poluição transfronteiriça das águas. Neste caso, o lançamento de substâncias poluentes nas águas de um rio ou mar, ou até mesmo próximo de lençóis freáticos, pode atingir tanto o território de um Estado, no qual se originou o dano, como no de outro. Observa-se assim, que os efeitos da danosidade se propagam de tal maneira que não se consegue identificar com precisão as fontes de emissão, situação que também pode ser notada nos fenômenos do efeito estufa e chuva ácida.

Diante da multiplicidade de riscos advindos das diversas inovações tecnológicas ligadas à chamada sociedade de risco teorizada por Beck, cada vez mais tem sido evidenciado a insegurança que permeia as relações humanas e, por consequência, também as de ordem jurídica. Neste contexto, a prova do nexo de causalidade para a imputação da responsabilidade civil ambiental demonstra ser, em certos casos, deveras difícil quando se considera a complexidade do bem ambiental e a incerteza científica. Neste sentido, apresenta-se alguns dos maiores entraves quando se trata de comprovar o nexo de causalidade do dano ambiental, conforme explica Bahia (2012, p. 67):

[...] a demonstração da autoria do comportamento danoso encontra novos obstáculos, pois o dano ambiental, frequentemente, é produto de uma pluralidade de ações praticadas por diversos sujeitos; não raro são os comportamentos sociais massificados que causam a degradação, havendo, portanto, autoria difusa (como é o caso, por exemplo, das mudanças climáticas); além disso, também é comum que a degradação seja fruto de comportamentos cumulativos, que se agravam ao longo do tempo, ou de comportamentos praticados em locais distantes daquele onde houve a manifestação do dano (efeitos transfronteiriços do dano ambiental).

Em interessante análise no contexto da sociedade de risco, Ulrich Beck defende a "revogação causal dos riscos" argumentando que o reconhecimento do risco é por vezes denegado pelos cientistas em função de sua incerteza científica, ocasionando assim um aumento de perigo. Explica o autor que são feitas concessões para a exploração da potenciação dos riscos visto que com a fixação de altos critérios de cientificidade para o 
reconhecimento destes são poucos os que integram tal lista fazendo com que, por outro lado, aumentem aqueles riscos que escapam da "malha científica" deixando assim a população mais suscetível aos riscos não reconhecidos cientificamente (BECK, 2011, p. 75).

Em uma abordagem vanguardista é apontada uma liberalização da prova causal dos riscos ambientais citando também suas consequências sociais, levando em consideração o fato de que tais riscos muitas vezes não possuem causas e/ou poluidores específicos, conforme argumenta Beck (2011, p. 76):

\footnotetext{
Uma liberalização da prova de causalidade equivaleria, nessas condições, ao rompimento do dique e, consequentemente, a uma inundação de ameaças e riscos a serem reconhecidos, que sacudiriam toda a estrutura social e política da Alemanha com a amplitude de seus efeitos. Desse modo, também aqui e como sempre - numa delicada harmonia entre ciência e direito -, o suposto "princípio da causação" é utilizado como eclusa de reconhecimento ou refutação: sabe-se que geralmente os riscos da modernização, em razão de sua estrutura, não podem ser suficientemente interpretados segundo o princípio da causação. (...) Com a inocência da pura "ciência", os pesquisadores do risco defendem a "fina arte da demonstração causal", bloqueiam assim protestos dos cidadãos, sufocam-nos ainda no ninho da "insuficiência" prova causal, parecem poupar custos à indústria, livrar as costas dos políticos e manter na verdade as eclusas abertas a uma ameaça generalizada à vida.
}

Diante disso, existe uma tendência exaltada pela doutrina no que se refere a dar novo sentido ao nexo causal, que seria a chamada inversão do ônus da prova previsto no art. $6^{\circ}$, VIII da Lei 8.078/1990 (Código de Defesa do Consumidor), que sem abandonar o liame, segundo Milaré (2020, p.1.255): “[...] não surpreenderá que o caminho a prosseguir conduza e justifique a instituição legal de um sistema assentado na inversão do ônus da prova, à semelhança do que já ocorre entre nós, em tema de relações de consumo [...]”.

Através de tal mecanismo será transmitido ao demandado o dever de provar que sua atividade não possui ligação com o dano ocorrido (ou sua iminência) o que deverá favorecer ao lesado demandante que por vezes é a parte hipossuficiente da demanda considerando os elevados custos para a realização de provas de acentuado teor técnico.

Frente às situações novas e complexas que se referem à reparação do dano ambiental e do nexo de causalidade é possível notar uma estreita dinâmica entre os aspectos científico e jurídico que, dado as peculiaridades do bem em questão, requer novos olhares quanto aos juízos de certeza, conforme leciona Bahia (2012, p. 68): 
[...] É precisamente o reconhecimento da função preventiva da responsabilidade civil ambiental e a sua importância para a proteção dos interesses das gerações futuras que respalda a constatação de que, na comprovação do nexo causal, o Poder Judiciário não deve utilizar juízos de certeza, mas juízos de verossimilhança e de probabilidade.

Outro ponto bastante discutido em sede de responsabilidade civil ambiental é quanto ao chamado limite de tolerabilidade. Tal mecanismo visa esclarecer até que ponto a ação humana sobre o meio ambiente deve ser considerada aceitável ou não. Sendo assim, nem toda lesão é considerada um dano ambiental (por exemplo, as mutações espontâneas da natureza) sendo comprovado o reconhecimento deste somente com relação àquelas condutas consideradas antijurídicas que lesam ou limitam o desenvolvimento da personalidade humana em decorrência do dano causado ao meio ambiente (LEITE; AYALA, 2015, p.201).

A Lei $6.938 / 81$, art. $3^{\circ}$, III, ao tratar sobre o assunto, estabeleceu como poluição a degradação da qualidade ambiental resultante de atividades que direta ou indiretamente: a) prejudiquem a saúde, a segurança e o bem-estar da população; b) criem condições adversas às atividades sociais e econômicas; c) afetem desfavoravelmente a biota; d) afetem as condições estéticas ou sanitárias do meio ambiente; e) lancem matérias ou energia em desacordo com os padrões ambientais estabelecidos.

Considerando o princípio do limite de tolerabilidade como fator relacionado diretamente com a certeza do dano ambiental defende Mirra (2004, p. 107):

[...] o princípio do limite de tolerabilidade, compreendido na sua exata significação, longe de consagrar um direito de degradar, emerge, diversamente, como um mecanismo de proteção do meio ambiente, tendente a estabelecer um certo equilíbrio entre as atividades interventivas do homem e o respeito às leis naturais e aos valores culturais que regem os fatores ambientais condicionantes da vida.

Ulrich Beck, no entanto, ao abordar os limites de tolerância nos moldes da sociedade de risco, os chama de "feitiço fajuto" argumentando que os cientistas ao estipularem tais limites para vestígios tóxicos na natureza e nas pessoas, simultaneamente, admitem as emissões poluentes e as legitimam dentro dos limites que estipulam, num jogo onde o "pouquinho" de envenenamento se transforma em normalidade, conforme explica:

Quem quer que limite a poluição estará fatalmente consentindo com ela. Aquilo que é ainda admissível é, por sua definição em termos sociais, "inofensivo" independente do quão daninho seja. Pode muito bem ser que os limites de tolerância evitem o pior, mas eles nem por isto deixam de ser um "álibi" para envenenar um pouquinho a natureza e o ser humano. O que importa saber é o quão grande pode 
chegar a ser esse "pouquinho". É questão sobre se é pequeno ou grande o pouquinho de veneno que flora, fauna e ser humano suportam, e o quão grande é o pouquinho, e o que significa "suportar" nesse caso - são essas as questões encantadoramente terríveis, saídas da sofisticada cozinha dos venenos e antídotos civilizacionais que estão implicadas na definição de limites de tolerância (BECK, 2011, p. 78).

Sendo assim, a responsabilidade civil ambiental na atualidade representa um grande desafio no caminho da prevenção e reparação ambientais, uma vez que a segurança jurídica e o princípio da precaução nem sempre são claramente compatíveis na sociedade de risco. No entanto, questões que envolvem certeza para tratar dos riscos incalculáveis e imprevisíveis requer uma postura mais avançada do próprio Direito no que tange a agir preventivamente (LEITE; BELCHIOR, 2012, p. 31).

Pode-se afirmar, portanto, que a falta de certeza do nexo causal não deve servir de desculpa para a não aplicação da responsabilidade ao degradador ambiental devendo-se, por outro lado, os operadores do Direito basear-se em critérios de probabilidade e verossimilhança a fim de evitar a existência de um direito adquirido de poluir.

\section{Conclusões}

É fato que o sistema clássico de responsabilidade civil baseado na culpa do agente (responsabilidade subjetiva) não era suficiente para a proteção dos danos ambientais devido à licitude de grande parte das condutas lesivas ao meio ambiente.

Assim, foi adotada pelo ordenamento jurídico brasileiro na seara ambiental, a teoria da responsabilidade objetiva fundada no risco apresentado pela atividade perigosa desenvolvida pelo agente. Na sociedade de consumo em que se vive, marcada pelo uso abusivo dos recursos naturais, era de se esperar a busca por uma adaptação da tutela ambiental aos paradigmas atuais.

Em virtude da sociedade de risco e da avalanche de novas situações a ela inerentes, principalmente quando se trata de riscos abstratos, necessário também um sistema de responsabilização não engessado que busque alternativas para a maior reparabilidade possível do dano ambiental.

O paradigma emergente pautado na visão holística, na abordagem sistêmica e na interdisciplinaridade tem seus reflexos na área jurídica e mais especificamente no Direito Ambiental. Com efeito, esta mudança trouxe a incorporação de uma nova hermenêutica sobre 
a juridicidade do dano ambiental e deu novas funções à responsabilidade civil através da observância de princípios estruturantes como o da dignidade da pessoa humana, a proteção da sadia qualidade de vida e a reparação integral do meio ambiente.

Neste contexto, diante do caráter difuso do dano ambiental e do processo de massificação de direitos da coletividade, a admissibilidade de reparação por dano moral ambiental coletivo, por exemplo, apresenta-se como uma forma de amoldamento da responsabilidade civil frente à nova qualidade de riscos da pós-modernidade.

\section{REFERÊNCIAS}

ADESTEFENNI, Marcos. A responsabilidade civil ambiental e as formas de reparação do dano ambiental: aspectos teóricos e práticos. Campinas: Bookseller, 2005.

ANTUNES, Paulo de Bessa. Direito Ambiental. Rio de Janeiro: Atlas, 2021.

BAHIA, Carolina Medeiros. Dano Ambiental e nexo de causalidade na sociedade de risco. In: Heline Silvini Ferreira; Maria Leonor Paes Cavalcanti Ferreira. (orgs.). Dano ambiental na sociedade de risco. São Paulo: Saraiva, 2012, p. 55- 80.

BECK, Ulrich. Sociedade de risco: rumo a uma outra modernidade. Tradução de Sebastião Nascimento. São Paulo: Editora 34, 2011.

BENJAMIN, Antonio Heman V. Responsabilidade cível pelo dano ambiental. Revista de Direito Ambiental, São Paulo: RT, jan., v.9, p. 7-11, 1998.

BROUWERS, Silvana do Prado; PEREIRA, Reginaldo. Sociedade de risco e racismo Ambiental na Globalização. Revista de Direito Ambiental. São Paulo: Revista dos Tribunais, no 61, p. 37-74, jan.-mar./2011.

CARVALHO, Délton Winter de. A proteção jurisdicional do meio ambiente: uma relação jurídica comunitária. Revista de Direito Ambiental, São Paulo: RT, N.24, p. 197, 2001.

DINIZ, Maria Helena. Curso de direito civil brasileiro, volume 7: responsabilidade civil. 35 ed. São Paulo: Saraiva, 2021.

FEITOZA, Paulo Fernando de Britto. Patrimônio Cultural - proteção e responsabilidade objetiva. Manaus: Editora Valer, 2012.

FIORILlO, Celso Antonio Pacheco. Curso de direito ambiental brasileiro. 20. ed. São Paulo: Saraiva, 2020.

GONÇALVES, Carlos Alberto. Responsabilidade civil. 10 ed. São Paulo: Saraiva, 2019.

LEITE, José Rubens Morato, AYALA, Patryck de Araújo. Dano Ambiental: do individual ao coletivo extrapatrimonial. 7. ed. rev., atual. e ampl.. São Paulo: Revista dos Tribunais, 2015. 
José Rubens Morato, BELCHIOR, Germana Parente Neiva. Dano ambiental na sociedade de risco: uma visão introdutória. In: Heline Silvini Ferreira; Maria Leonor Paes Cavalcanti Ferreira. (orgs.). Dano ambiental na sociedade de risco. São Paulo: Saraiva, 2012, p. 13-54.

MILARÉ, Édis. Direito do ambiente: a gestão ambiental em foco: doutrina jurisprudência, glossário. 12. ed. rev., atual. e reform. São Paulo: Revista dos Tribunais. 2020.

MIRRA, Álvaro Luiz Valery. Ação civil pública e a reparação do dano ao meio ambiente. $2^{a}$ ed. atual. - São Paulo: Juarez de Oliveira, 2004.

RODRIGUEIRO, Daniela A. Dano Moral ambiental: sua defesa em juízo, em busca de vida digna e saudável.São Paulo: Editora Juarez de Oliveira, 2004.

SILVA, José Afonso da. Direito Ambiental Constitucional. 12. ed. atual. São Paulo: Malheiros, 2021.

STEIGLEDER. Annelise, Monteiro. Responsabilidade Civil Ambiental: As dimensões do dano ambiental no direito brasileiro. Porto Alegre: Livraria do Advogado, 2004.

TRENNEPOHL, Terence Dorneles. Direito Ambiental. 4. Ed. Bahia: Juspodivm. 2009.

VENOSA, Sílvio e Salvo. Direito civil: responsabilidade civil. 16 ed. São Paulo: Atlas, 2016. 